\title{
Olfactory inhibition and recovery in chum salmon (Oncorhynchus keta) following copper exposure
}

\author{
Jason F. Sandahl, Go Miyasaka, Nobuhisa Koide, and Hiroshi Ueda
}

\begin{abstract}
Copper can be an effective hatchery treatment to control certain parasitic and fungal infections in salmonids, yet it is also highly toxic to the fish's olfactory system. Numerous reports have described the early inhibitory impacts of copper on fish olfaction, but very few have addressed processes of recovery. Here we show that the chum salmon (Oncorhynchus keta) olfactory system can recover from short-term (4 h) exposures to copper $\left(3-58 \mu \mathrm{g} \cdot \mathrm{L}^{-1}\right) \mathrm{within}$ 1 day, as indicated by electro-olfactogram (EOG) recordings. Recovery followed initial EOG reductions of up to $88 \%$. We also applied a novel cytophysiological approach to monitor changes in the olfactory receptor cells using a fluorescent styryl dye, AM1-43. Copper's influence on the number of receptor cells that labelled with the dye was biphasic, initially increasing the number at the two lowest copper concentrations $\left(3\right.$ and $\left.8 \mu \mathrm{g} \cdot \mathrm{L}^{-1}\right)$ and decreasing the number at the two highest concentrations $\left(24\right.$ and $\left.58 \mu \mathrm{g} \cdot \mathrm{L}^{-1}\right)$. Changes in the ability of olfactory receptor neurons to internalize the dye were monitored up to 10 days in fish recovering from copper exposure.
\end{abstract}

Résumé : Le cuivre peut servir de traitement efficace des piscicultures afin de contrôler certaines infections à parasites ou à champignons chez les salmonidés, bien qu'il soit très toxique pour le système olfactif des poissons. De nombreux travaux ont décrit les premiers effets inhibiteurs du cuivre sur l'olfaction des poissons, mais très peu se sont intéressés aux processus de récupération. Nous montrons ici que le système olfactif du saumon kéta (Oncorhynchus keta) peut récupérer après de courtes $(4 \mathrm{~h})$ expositions au cuivre $\left(3-58 \mu \mathrm{g} \cdot \mathrm{L}^{-1}\right)$ en moins d'une journée, d'après les enregistrements d'électro-olfactogrammes (EOG). La récupération fait suite à des réductions initiales de l'EOG pouvant atteindre $88 \%$. Une nouvelle méthode cytophysiologique utilisant un colorant styryle fluorescent, AM1-43, permet de suivre les changements dans les cellules olfactives réceptrices. L'effet du cuivre sur le nombre de cellules réceptrices marquées par le colorant se fait en deux phases, au départ une augmentation du nombre aux deux concentrations les plus faibles de cuivre $\left(3\right.$ et $\left.8 \mu \mathrm{g} \cdot \mathrm{L}^{-1}\right)$ et une diminution aux deux concentrations les plus élevées $\left(24 \mathrm{et} 58 \mu \mathrm{g} \cdot \mathrm{L}^{-1}\right)$. Nous avons suivi les changements de la capacité des neurones olfactifs récepteurs d'incorporer le colorant jusqu'à 10 jours chez des poissons en train de récupérer d'une exposition au cuivre.

[Traduit par la Rédaction]

\section{Introduction}

Short-term exposures to dissolved copper (on the order of minutes to hours) and at relatively low concentrations (1-20 $\left.\mu \mathrm{g} \cdot \mathrm{L}^{-1}\right)$ can inhibit the electrical properties of olfactory receptor neurons in salmon (Baldwin et al. 2003; Sandahl et al. 2004). Copper targets several sites of the olfactory neuron, and depending on the conditions of exposure, inhibitory effects can be either reversible or irreversible (Moran et al. 1992; Julliard et al. 1996; Hansen et al. 1999). Irreversible damage caused by high or prolonged exposures to copper can target cellular surface proteins, membrane structure, or internal organelles and can eventually lead to cell death (Brown et al. 1982). Subsequent regeneration of the neurons may require several weeks. Less attention, however, has been given to the reversible effects of copper on the fish olfactory system and the time required for recovery, following relatively brief or low concentration exposures.

In urban and agricultural environments, exposures to copper can occur when storm water pulses into an aquatic habitat (Anderson et al. 1996; Soller et al. 2005; Wheeler et al. 2005). In a hatchery setting, fish can be intentionally treated with copper to control disease (e.g., Schlenk et al. 1998). Olfaction plays an essential role in the survival of salmon, and the olfactory nervous system is highly sensitive to the impacts of surface water toxicants, such as copper. Odorant cues convey important information about the aquatic environment, including the chemical constituents of natal habitat, habitat quality, the presence and location of food, conspecifics and predators, and the reproductive status of spawning partners. It is therefore important that brief copper exposures to salmon, either as pulses into the environment or

Received 22 July 2005. Accepted 27 March 2006. Published on the NRC Research Press Web site at http://cjfas.nrc.ca on 18 July 2006.

$\mathrm{J} 18804$

J.F. Sandahl, ${ }^{1}$ G. Miyasaka, and H. Ueda. Laboratory of Aquatic Bioresources and Ecosystems, Field Science Center for Northern Biosphere, Hokkaido University, North 9 West 9, Kita-ku, Sapporo, Hokkaido 060-089, Japan.

N. Koide. Hokkaido Fish Hatchery, Eniwa, Hokkaido 061-1433, Japan.

${ }^{1}$ Corresponding author (e-mail: sandahljf@yahoo.com). 
as treatments by hatchery managers, do not cause long-lasting olfactory impairment.

The electro-olfactogram (EOG) has been one of the primary tools for monitoring the inhibitory effects of toxicants on electrical field potentials of olfactory receptor neurons in fish (e.g., Hara et al. 1976). Upon binding of odorant agonists, populations of $\mathrm{G}$ protein-coupled receptors (GPCR) transduce stimuli information to second messengers within the neuron, creating a generator potential that triggers an action potential (Ferguson 2001). An electrode positioned above the surface of the olfactory epithelium measures the summated electrical responses from stimulated neurons and is recorded as the EOG (Hara 1992).

The EOG has been useful in studying the effects of contaminants on primary sensory neurons of the olfactory system, particularly in fish (Baatrup et al. 1990; Jarrard et al. 2004; Sandahl et al. 2004). Heavy metals, for example, can inhibit the electrical properties of olfactory neurons, presumably by blocking ligand-gated and (or) voltage-gated ion channels. This inhibitory effect can be reversible, as indicated by time-course EOG recordings in salmon (Baldwin et al. 2003). However, more severe, irreversible damage to a neuron ultrastructure by metals, including the GPCR-rich cilia and microvilli, the cellular membrane, and supportive organelles, can result in extended reductions in neuronal electrical activity.

Few data are available describing the subtle impacts that heavy metals and other contaminants can have on the complex mechanics of the olfactory process. Toxins can target a number of sites along the agonist-transduction-messengerelectrical signaling pathway, ultimately resulting in inhibitory, excitatory, or distorted responses reaching the olfactory bulb (Horning and Trombley 2001; Sandahl et al. 2004). Along with ion channels as initial targets of heavy metals, odorant-binding GPCRs are also susceptible sites. Metals, like copper, may act as odorant agonists, alter a receptor protein's steric properties, alter transduction or second messenger pathways, or affect processes involving GPCR endocytosis and recycling. Although few studies have addressed this area of metal toxicity in the olfactory system, related research may provide useful tools to begin.

Fluorescent styryl dyes, such as AM1-43 and similar dyes, have been used to investigate synaptic activity at neuron terminals (Pyle et al. 1999; Cousin and Robinson 2000; Li et al. 2003). In these previous studies, the styryl dyes were shown to enter active neurons via endocytosis following nerve stimulation. Although there are no synaptic connections at the apical surface of olfactory receptor neurons - the initial target site of copper toxicity — we speculated that similar endocytic processes of the olfactory receptor neuron would also allow the dye to penetrate an active cell.

In the present study, we combined the two techniques, the EOG and AM1-43 labelling of olfactory receptor neurons in chum salmon (Oncorhynchus keta), to address a practical problem faced by hatchery managers in northern Japan. In Japanese aquaculture, treatment of fungal and parasitic infections in salmonids has often been carried out using the chemical agent, formalin. Because of its carcinogenic risks, the use of formalin at Japanese hatcheries has mostly been eliminated. At the Hokkaido Fish Hatchery (Eniwa, Japan), preliminary experiments have demonstrated that copper treatments can reduce infections caused by the fungus Saprolegnia in chum salmon roe and reduce the parasite Ichthyobodo necator in chum and masu salmon (i.e., cherry salmon, Oncorhynchus masou masou) fry (N. Koide, unpublished data). But while copper may be efficacious for disease control and is relatively nontoxic to human handlers, managers are cautious in using copper because of its known toxicity to the salmonid olfactory organ.

The goal of this current study was first to measure the initial impacts of copper, at hatchery treatment concentrations, on the electrical properties of olfactory receptor neurons in chum salmon fry using a traditional electrophysiological method, the EOG. We also attempted to use a novel cytophysiological approach, functional dye labelling, to visually mark active neurons. We then used these two techniques to monitor olfactory recovery over 10 days.

\section{Materials and methods}

\section{Animals}

Experiments were carried out using chum salmon obtained from the Hokkaido Fish Hatchery (Eniwa, Japan) and raised at Hokkaido University Toya Lake Station for Environmental Biology (Toya, Japan) under natural photoperiod conditions. Fish were maintained in tanks supplied with filtered spring water $\left(40 \mathrm{mg} \cdot \mathrm{L}^{-1}\right.$ total hardness as $\mathrm{CaCO}_{3}, \mathrm{pH}$ 6.1, conductivity $0.14 \mathrm{mS} \cdot \mathrm{cm}^{-1}$, turbidity 0.0 nephelometric turbidity units (NTU), dissolved oxygen $9.1 \mathrm{mg} \cdot \mathrm{L}^{-1}$, and temperature $9.7{ }^{\circ} \mathrm{C}$ ) in a single-pass flow system. Fish were raised on standard commercial salmon pellets. The chum fry were $2-$ 3 months in age, mean length ( \pm standard deviation, SD) $4.9 \pm 0.3 \mathrm{~cm}$, and weight $0.8 \pm 0.2 \mathrm{~g}$.

\section{Chemical solutions}

A concentrated stock copper solution was prepared at the Hokkaido Fish Hatchery using a copper ion generator (ABLE Co. Ltd., Tokyo, Japan). Similar to the methods used by hatchery managers to prepare copper solutions for disease control, our exposure solutions were prepared by adding varying amounts of copper stock to spring water in glass aquaria $(25 \mathrm{~L})$. Triplicate samples collected from control and exposure tanks (four concentrations of copper) were preserved with $0.1 \mathrm{~mol} \cdot \mathrm{L}^{-1}$ nitric acid ( $1 \%$ of total volume), filtered through a $0.45 \mu \mathrm{m}$ membrane, and then analyzed for total copper content along with quality assurance copper standards and blanks. Analyses were conduced at the Hokkaido Fish Hatchery using atomic absorption spectroscopy (Hitachi Z-6000 Ltd., Tokyo, Japan). Spring water control solutions were found to contain a background level of $0.0 \mu \mathrm{g} \cdot \mathrm{L}^{-1}$ total dissolved copper (detection limit $0.05 \mu \mathrm{g} \cdot \mathrm{L}^{-1}$ ). Exposure solutions contained 3, 8, 24, and $58 \mu \mathrm{g} \cdot \mathrm{L}^{-1}$ copper.

An odorant solution containing $10 \mathrm{mmol} \cdot \mathrm{L}^{-1} \mathrm{~L}$-serine (Wako Pure Chemical Industries, Tokyo, Japan) was prepared daily in spring water from a concentrated stock of the amino acid. Hatchery outlet stream water (considered the home stream for returning, station-raised fish, with a presumably complex odorant composition) was collected in a $1 \mathrm{~L}$ glass jar at its discharge point into Lake Toya, refrigerated, and used daily throughout the duration of the experiment. Outlet water had the following characteristics: $75 \mathrm{mg} \cdot \mathrm{L}^{-1}$ total hardness as 
$\mathrm{CaCO}_{3}$, pH 6.7 , conductivity $0.15 \mathrm{mS} \cdot \mathrm{cm}^{-1}$, turbidity 2 NTU, and dissolved oxygen $11.3 \mathrm{mg} \cdot \mathrm{L}^{-1}$.

\section{Copper exposures and electrophysiological recordings}

Fish were treated for $4 \mathrm{~h}$ in copper-treated spring water (in groups of six fish each). After the exposure period, a single fish was removed from the group for electrophysiological tests, while the remaining fish were transferred to a flow-through spring water tank for recovery (for $1,4,7$, or 10 days). This process was repeated six times at each copper concentration ( $n=6$ fish per copper concentration). On each recovery day, six fish per exposure group were selected for EOG tests ( $n=6$ fish per recovery day). At least one control fish (copper blank exposure) was tested each day over the course of the experiment ( $n=15$ total).

Prior to EOG tests, fish were anaesthetized in eugenol (2methoxy-4-(2-propenyl) phenol) at $50 \mu \mathrm{L} \cdot \mathrm{L}^{-1}$ and then placed in a holder on a vibration isolation table. Oxygenated spring water containing $20 \mu \mathrm{L} \cdot \mathrm{L}^{-1}$ eugenol irrigated the gills through a mouthpiece. Earlier tests performed in our laboratory indicated that similar eugenol exposures did not impair olfactory sensitivity salmon (Y. Yamamoto, Division of Environmental Science Development, Graduate School of Environmental Science, Hokkaido University, North 9 West 9, Kita-ku, Sapporo, 060-0809, Japan, unpublished data). The responsive properties of the olfactory receptor neurons were recorded by using a pair of glass microelectrodes filled with $2.5 \%$ agar-saline and bridged to a silver wire. With the aid of a stereomicroscope and micromanipulators, an odorant perfusion tube was inserted gently into the in-current passage of the nare, and the recording microelectrode was inserted through the ex-current passage and positioned above the midline of the rosette at the base of posterior-most lamella. A reference microelectrode was placed on the head, and a separate ground electrode was clipped to the tail of the fish. The differential electrical signal was amplified (500x) and filtered (100 Hz low-pass) using a direct current amplifier (A-M Systems, Carlsborg, Washington, USA). The signals were digitized at 10 samples $\cdot \mathrm{s}^{-1}$ using PicoScope data acquisition software (Pico Technology Ltd., St. Neots, UK), and the signal amplitudes were measured in millivolts $(\mathrm{mV})$.

After electrode placement, the olfactory rosettes were rinsed for $15 \mathrm{~min}$ with spring water at a steady rate of $1 \mathrm{~mL} \cdot \mathrm{min}^{-1}$. Odorants were then pulsed for $10 \mathrm{~s}$ into the spring water three times, each pulse separated by $150 \mathrm{~s}$. EOGs were recorded in response to L-serine $\left(10 \mathrm{mmol} \cdot \mathrm{L}^{-1}\right)$ and hatchery outlet stream water. The amplitude of the EOG response was quantified by the negative phasic displacement of the odorevoked peak relative to the prestimulus electrical baseline.

\section{Olfactory receptor neuron labelling using AM1-43}

Fluorescent dye AM1-43 $\left(\mathrm{C}_{29} \mathrm{H}_{49} \mathrm{Cl}_{3} \mathrm{~N}_{4}\right.$, molecular weight $=$ 559.5) was purchased from Biotium, Inc. (Hayward, California, USA). A concentrated stock solution of the dye (100 $\mu \mathrm{mol} \cdot \mathrm{L}^{-1}$ ) was made in distilled water and stored in $500 \mu \mathrm{L}$ aliquots at $-20{ }^{\circ} \mathrm{C}$.

For method development, solutions of AM1-43 dye were prepared in spring water and adjusted to $\mathrm{pH} 7.0$ with diluted $\mathrm{NaOH}$. Dye concentrations $\left(1,5,10\right.$, and $\left.20 \mu \mathrm{mol} \cdot \mathrm{L}^{-1}\right)$ and dye perfusion times $(15,30,60$, and $120 \mathrm{~s})$ were tested to determine appropriate parameters for later copper exposure experiments. We sought a combination of these two parameters that would allow individual cells to be distinguishable and also allow either increases or decreases in labelled cell numbers to be observed clearly. We also tested the use of a fluorescence quencher (SCAS; Biotium, Inc.) for removing background staining from the epithelial surface, but found that rinsing with clean spring water was sufficient for the purpose of this study. Based on these preliminary dye experiments, immediately following EOG testing, rosettes of fish were perfused for $30 \mathrm{~s}$ with AM1-43 $\left(10 \mu \mathrm{mol} \cdot \mathrm{L}^{-1}\right)$ and then rinsed with clean spring water for $3 \mathrm{~min}$. The anterior portion of the snout containing the olfactory chamber was then excised and placed overnight in approximately $10 \mathrm{~mL}$ of a $1 \%$ paraformaldehyde, $2.5 \%$ glutaraldehyde fixative solution. The rosette was then extracted from the olfactory chamber and embedded in 10\% agar gel. Rosettes were sectioned at $30 \mu \mathrm{m}$ using a Vibratome DTK-2000 (Dosaka EM, Kyoto, Japan).

Labelled cells were found distributed evenly among the several lamella of the rosette. For consistency between animals and for sufficient statistical power in analyses, five midregion sections from the largest, anterior-most lamella of the rosette from each fish was arbitrarily selected for cell counting. Sections were magnified at $200 \times$ using a fluorescent microscope (Axioskop, Carl Zeiss, Gotingen, Germany) filtered at 450-490 $\mathrm{nm}$. Color digital images were captured using a charge-coupled device (CCD) camera (model VB7010, Keyence, Osaka, Japan) and imaging software (model VH-H1A5, Keyence), and individual cells were counted manually. The fluorescent images were converted to grayscale and intensity inverted using Adobe Photoshop Elements 1.0 (Adobe Systems, Inc., San Jose, California, USA) for publication.

Labelling appeared to be nonselective for cell type (e.g., microvillar, ciliated, crypt), as determined by cell morphology (Sato and Suzuki 2001; Belanger et al. 2003; Hansen et al. 2003) and position in the epithelium (Hansen and Finger 2000; Hamdani et al. 2001; Hamdani and Døving 2002). For cells to be accepted as labelled, the entire dendrite leading to the apical surface and the cell body had to be clearly defined. All olfactory receptor cell types were included in counting.

\section{Statistics}

Statistical analyses and graphing were performed using GraphPad Prism 4.0 (San Diego, California, USA). Differences in EOG amplitudes and differences in fluorescent cell numbers were compared using one-way analysis of variance (ANOVA), followed by a Dunnett post hoc multiple comparison test.

\section{Results}

\section{EOG reduction and recovery following $4 \mathrm{~h}$ copper exposures}

Mean EOG amplitudes (standard error, SE) stimulated by L-serine and outlet stream water were $2.8 \pm 0.2 \mathrm{mV}$ and $3.2 \pm$ $0.1 \mathrm{mV}$, respectively. Typical examples of L-serine-evoked EOGs for control $\left(0 \mu \mathrm{g} \cdot \mathrm{L}^{-1}\right)$ and copper-exposed $\left(3-58 \mu \mathrm{g} \cdot \mathrm{L}^{-1}\right)$ fish are shown (Fig. 1a). Exposures to copper reduced the olfactory responses of chum fry to both odorants in a con- 
Fig. 1. (a) Typical examples of electro-olfactogram (EOG) recordings from chum salmon fry (Oncorhynchus keta) exposed to copper. Inhibition and subsequent recovery of odorant-evoked EOGs; (b) $10^{-3} \mathrm{~mol} \cdot \mathrm{L}^{-1}$ serine, (c) hatchery outlet water. Mean control EOG amplitudes are shown as horizontal solid lines extending from single solid circles; parallel dashed lines represent 95\% confidence intervals. Open symbols represent copperexposed groups: triangle, $3 \mu \mathrm{g} \cdot \mathrm{L}^{-1}$; square, $8 \mu \mathrm{g} \cdot \mathrm{L}^{-1}$; diamond, $24 \mu \mathrm{g} \cdot \mathrm{L}^{-1}$; circle, $58 \mu \mathrm{g} \cdot \mathrm{L}^{-1}$. Error bars represent \pm 1 standard error; asterisks indicate significant differences from the control group at $p<0.05$.

(a)

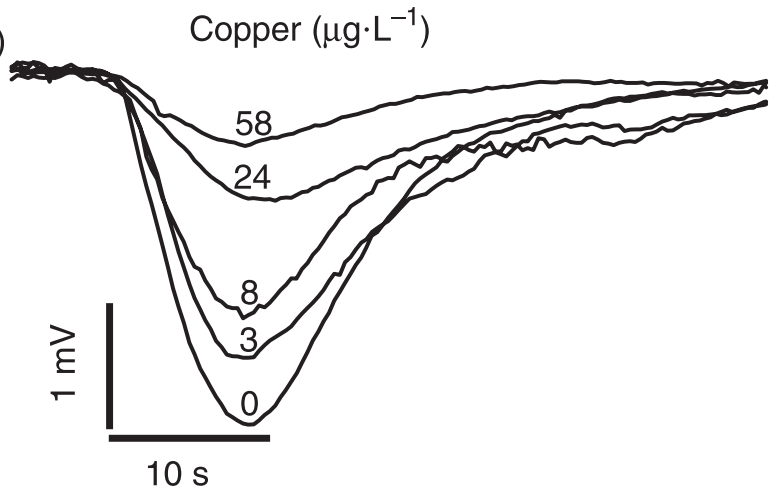

(b)
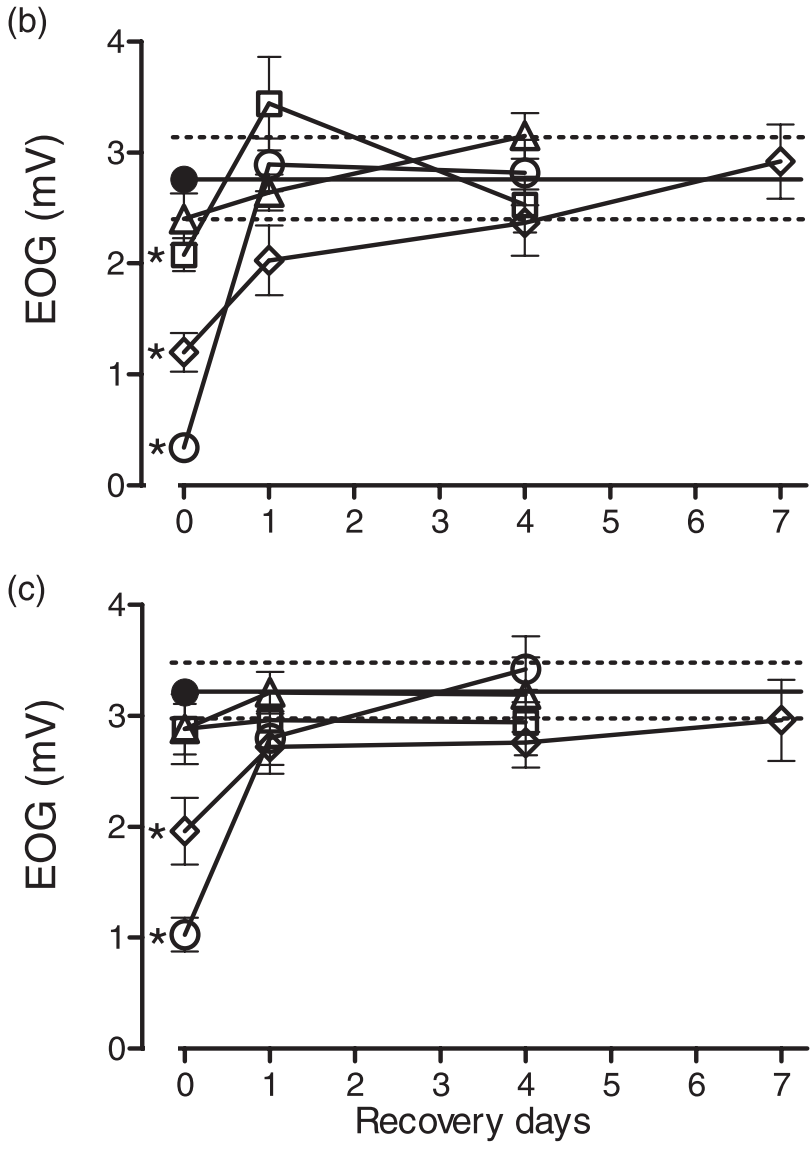

centration-dependent manner (Figs. 1b, 1c; ANOVA, $p<$ 0.05). During the recovery period over 7 days, EOG responses increased in all exposure groups and were statistically similar to the control group after 1 day and beyond (ANOVA, Dunnett test, $p>0.05$ for all groups).

Fig. 2. (a) Dye concentration and (b) perfusion time influence the number of olfactory receptor neurons that label with AM143, as shown in epithelial sections (first four panels) and in whole olfactory rosettes (fifth panel). (c) Examples of various olfactory receptor neurons that label with AM1-43.

(a)
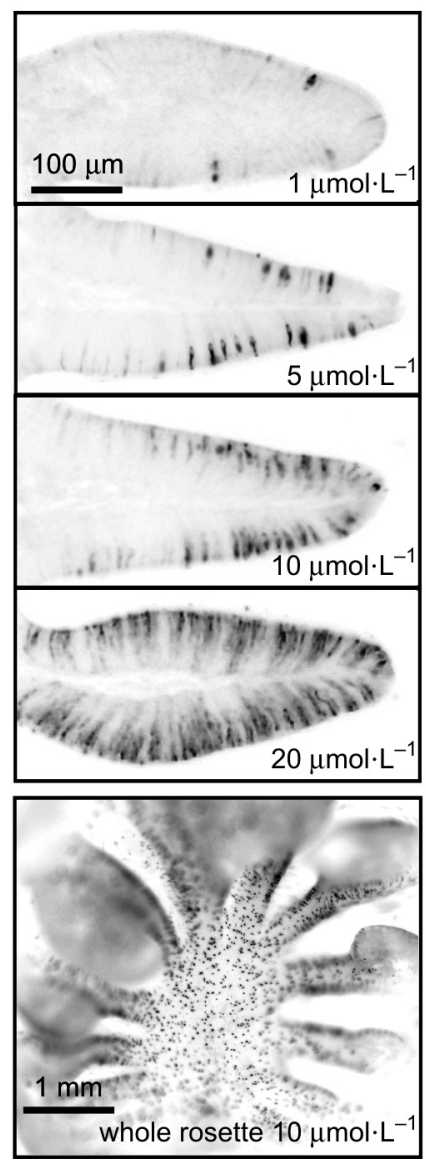

(c)

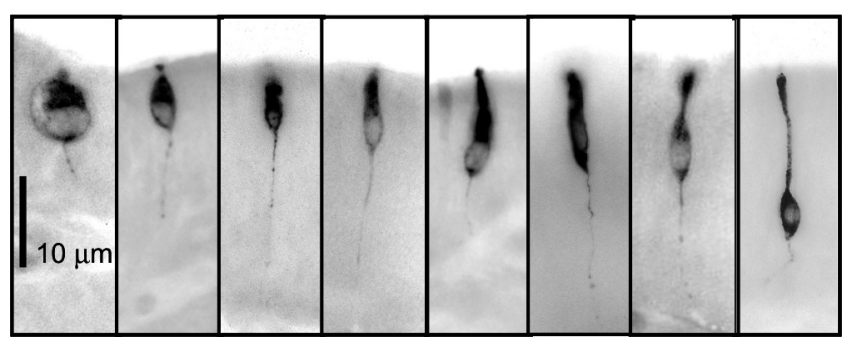

\section{Fluorescent labelling of olfactory receptor neurons following copper exposures}

Increasing dye concentration and dye perfusion time subsequently increased the number of olfactory receptor neurons that labelled in fish not exposed to copper. The labelled neurons were distributed evenly throughout the intact rosette, and typical examples of epithelial sections and whole rosettes revealing individually labelled neurons are shown (Figs. $2 a$ and $2 b$, respectively). Various olfactory receptor neurons (cell types not specified) that internalized AM1-43 are shown (Fig. 2c). Labelling did not appear to be odorant- 
Fig. 3. (a) Copper exposures alter the number and pattern of olfactory receptor neurons that label with AM1-43. (b) The mean number of labelled cells from controls is shown as a horizontal solid line extending from a single solid circle; parallel dashed lines represent a 95\% confidence interval. Open symbols represent copper-exposed groups: triangle, $3 \mu \mathrm{g} \cdot \mathrm{L}^{-1}$; square, $8 \mu \mathrm{g} \cdot \mathrm{L}^{-1}$; diamond, $24 \mu \mathrm{g} \cdot \mathrm{L}^{-1}$; circle, $58 \mu \mathrm{g} \cdot \mathrm{L}^{-1}$. Error bars represent \pm 1 standard error; all exposure groups were significantly different from the control group at $p<0.05$.

dependent, as indicated by additivity tests in which varying concentrations of L-serine $\left(10^{-3}, 10^{-4}\right.$, and $\left.10^{-5} \mathrm{~mol} \cdot \mathrm{L}^{-1}\right)$, combined with AM1-43 $\left(10 \mu \mathrm{mol} \cdot \mathrm{L}^{-1}\right)$, increased the amplitude of the EOG, but did not alter the number of cells that labelled with dye (data not shown).

Exposures to copper altered the pattern and number of olfactory receptor neurons that labelled with AM1-43 (Figs. $3 a, 3 b$ ). In the control group of fish, the mean number $( \pm \mathrm{SE})$ of labelled cells per $1 \mathrm{~mm}$ of epithelial tissue, at a thickness of $30 \mu \mathrm{m}$, was $42.2 \pm 5.5$ cells. After $4 \mathrm{~h}$ exposures to 3 and $8 \mu \mathrm{g} \cdot \mathrm{L}^{-1}$ copper, the number of cells that labelled increased significantly $(68.8 \pm 4.7$ and $96.5 \pm 10.8$ cells, respectively) as compared with the control group (ANOVA, Dunnett's test, $p<0.05)$. However, at 24 and $58 \mu \mathrm{g} \cdot \mathrm{L}^{-1}$ there were significant decreases in the number of cells that labelled $(26.4 \pm 7.1$ and $11.8 \pm 5.7$ cells, respectively) as compared with the control group (ANOVA, Dunnett's test, $p<$ $0.01)$. In the $24 \mu \mathrm{g} \cdot \mathrm{L}^{-1}$ copper group, internalization of the dye was often confined to the apical regions of the dendrites, and some background staining of debris occurred at the surface of the epithelium. At $58 \mu \mathrm{g} \cdot \mathrm{L}^{-1}$ copper, very few cell bodies or dendrites internalized AM1-43, and the surface of the epithelium showed substantial background staining.

Unlike the EOGs, fluorescent labelling of cells did not return to the level of the control group after 1 day (Fig. 3b). In fact, the number of cells that labelled in all copper-exposed groups declined below the control number, which continued through day four. The $24 \mu \mathrm{g} \cdot \mathrm{L}^{-1}$ exposure group was monitored for 10 days, after which the mean number of labelled cells showed only a partial return to the control group number.

\section{Discussion}

The degree of copper toxicity to the olfactory system in fish is dependent on both exposure concentration and exposure time (e.g., Saucier and Astic 1995). The combination of these parameters (in addition to other parameters, such as water chemistry, acclimation of fish to the test water, etc.) will influence the degree of impact on target sites and ultimately whether the toxic effects are reversible (short-term) or irreversible (long-term). The initial targets of copper on olfactory receptor neurons are believed to be proteins associated with odorant receptors, ion channels, and intracellular transduction mechanisms (Rhenberg and Schreck 1986; Winberg et al. 1992; Bjerselius et al. 1993). Longer exposures to copper at relatively high concentrations can damage cilia and microvilli located at the cellular surface, rupture the cellular membrane, or critically impair the protein-rich mitochondria and other organelles of the cytoplasm (Moran (a)
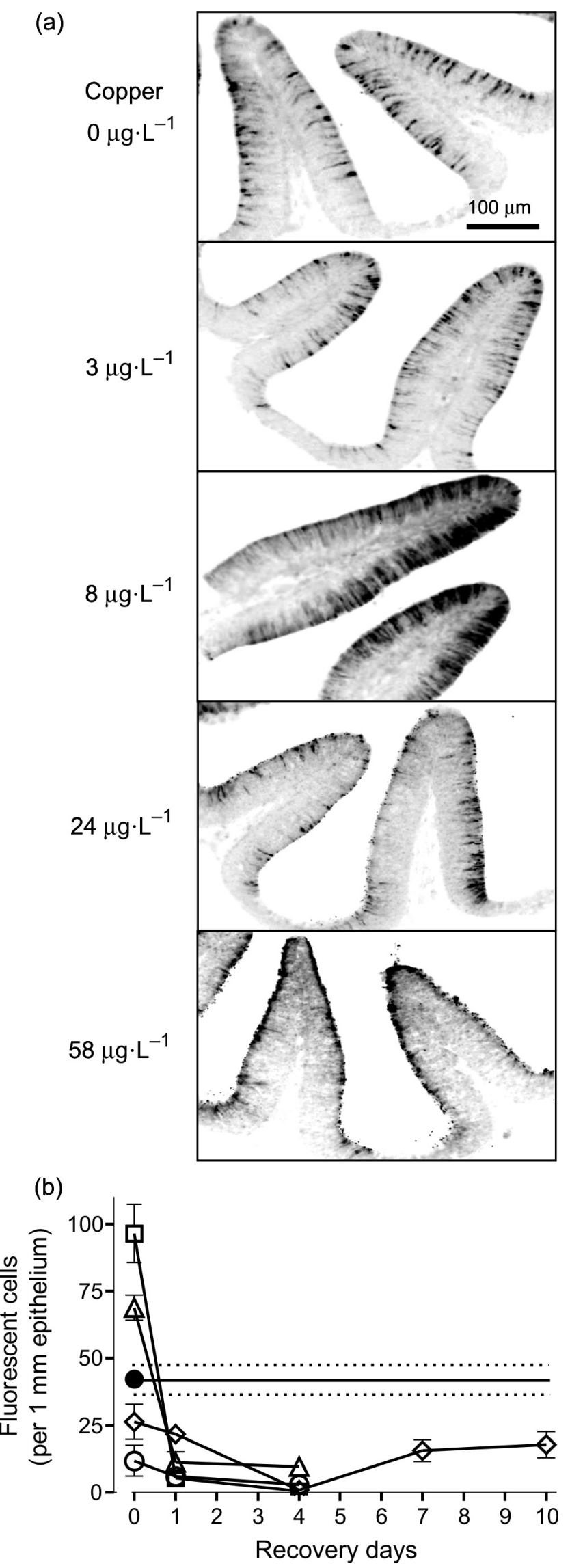
et al. 1992; Hansen et al. 1999). Severe damage to olfactory receptor neurons can lead to necrosis or apoptosis, requiring the entire regeneration of receptor cells (Moran et al. 1992; Julliard et al. 1996; Hansen et al. 1999). In this current study, electrophysiological olfactory function in chum salmon fry recovered to control levels after just 1 day, indicating that the toxic effect of copper on the electrical properties of the neurons was generally reversible.

The fluorescent dye AM1-43 has previously been used as a nerve terminal probe to follow neurotransmitter activity at central or neuromuscular synapses (Henkel et al. 1996; Kay et al. 1999; Pyle et al. 1999) or to measure activity of sensory cells triggered by mechanotransduction mechanisms (Meyers et al. 2003; Gale et al. 2001). AM1-43 has two carbon chain lipophilic tails at one end and a highly hydrophilic, cationically charged head group at the other. AM1-43 can enter nerve terminals by inserting into the outer layer of the cellular membrane, then moving into the cell via clathrin-mediated endocytosis within packets containing recycled neurotransmitter molecules. It can also enter the cells via certain large, nonspecific ion channels of the sensory neurons (Meyers et al. 2003).

Here, we show that AM1-43 can also label olfactory receptor neurons in intact fish by perfusing the dye over the olfactory rosette. Labelling was not dependent on the presence of an odorant. The number of labelled cells did not increase when AM1-43 was combined with L-serine, suggesting that internalization of the dye does not occur via a pathway related to the neuron electrical generator potential. Exposures to copper dramatically changed labelling patterns of the neurons, altering AM1-43 uptake into cells in a biphasic, concentration-dependent manner by an unspecified mechanism.

Although copper can be highly toxic to the olfactory neuron, it is also an essential trace metal. Copper is required for the proper functioning of several enzymes and has been shown to play an important role in odorant binding for some receptor proteins (Wang et al. 2003). Copper is also necessary in the synthesis of certain neuropeptides within the olfactory system (Rutkoski et al. 1999) and is believed to be a neuromodulator at various receptor synapses of the olfactory bulb (Trombley and Shepherd 1996; Acuna-Castillo et al. 2000; Horning et al. 2000). Studies in both mammals and fish have shown that certain heavy metals are actively directed to the olfactory bulb via anterograde axonal transport from the epithelium (Gottofrey and Tjälve 1991; Tallkvist et al. 1998, 2002). However, to our knowledge, a specific mechanism for the active uptake of the metals by olfactory neurons at the epithelial surface has not yet been identified.

One such mechanism may be similar to that of human kidney cell lines. These cells contain human copper transporter (hCtr1) proteins at the membrane surface that assist in the uptake and regulation of cellular copper (Petris et al. 2003). This protein is continuously recycled at the plasma membrane, even in the absence of copper, by clathrinmediated endocytosis, and the vesicles are then trafficked to endosomes within the cell. Under low copper conditions, Petris et al. (2003) found an up-regulation of hCtr1 protein expression at the plasma membrane, which in turn, would serve to elevate uptake of copper via increased endocytosis, possibly of a copper-hCtr1 complex. Higher levels of copper caused degradation of the hCtr1 protein at the plasma membrane, which in turn may have provided a protective mechanism to restrict further copper uptake. Fish olfactory receptor neurons may contain a similar metal-sequestering mechanism (Tjälve et al. 1986; Horning and Trombley 2001; Tallkvist et al. 2002). In the brown trout (Salmo trutta), various tissues, including the olfactory apparatus and kidney, also accumulated dissolved metal in a biphasic, concentrationdependent manner (Tjälve et al. 1986). Lower cadmium exposures resulted in higher tissue metal accumulations, whereas the pattern was reversed when the fish were exposed to higher cadmium concentrations. Further research is necessary to identify the specific mechanism for copper regulation in the olfactory receptor neurons of fish.

Under our experimental conditions, the electrophysiological responses of primary olfactory neurons in chum salmon fry recovered from short-term copper exposures after 1 day. For hatchery salmon, this brief disruption to olfaction may not be life-threatening or cause long-term harm. Fish in the wild are not afforded the protection of a hatchery, however, and even a relatively short loss of olfactory ability could impair essential survival strategies (Beyers and Farmer 2001; Mirza and Chivers 2001). Although electrical properties of the olfactory system recovered quickly in this study, unspecified cytophysiological properties of the olfactory receptor neurons remained altered up to 10 days after exposure, as suggested by sustained decreases in cells that labelled with AM1-43. The significance of this finding is not yet clear, but we believe that dyes such as AM1-43 will be useful in helping to understand mechanisms of metal regulation and toxicity in the fish olfactory system. How salmonids can acclimate, and indeed thrive, in some natural waters with relatively high copper concentrations is an important question, especially for regulators concerned about copper inputs from nonnatural sources. This will serve as the basis for future investigations.

\section{Acknowledgements}

This research was supported by a postdoctoral fellowship to J.F.S. from the Japan Society for the Promotion of Science (JSPS; PE 03509) and was supported in part by grant No. JSPS-RFTF 97L00901 from the "Research for Future Program", a grant from the River Front Foundation, and a grant from the Mitsubishi Foundation to H.U. Special appreciation goes to the staff and managers of the Hokkaido Fish Hatchery.

\section{References}

Acuna-Castillo, C., Morales, B., and Huidobro-Toro, J.P. 2000. Zinc and copper modulate differentially the P2X4 receptor. J. Neurochem. 74: 1529-1537.

Anderson, C.W., Rinella, F.A., and Rounds, S.A. 1996. Occurrence of selected trace elements and organic compounds and their relation to land use in the Willamette River basin, Oregon, 1992 94. US Geological Survey, Portland, Oreg. Water-Resource Invest. Rep. 96-4234

Baatrup, E., Døving, K.B., and Winberg, S. 1990. Differential effects of mercurial compounds on the electroolfactogram (EOG) of salmon (Salmo salar L.). Ecotoxicol. Environ. Saf. 20: 269-276. 
Baldwin, D.H., Sandahl, J.F., Labenia, J.S., and Scholz, N.L. 2003. Sublethal effects of copper on coho salmon: impacts on nonoverlapping receptor pathways in the peripheral olfactory nervous system. Environ. Toxicol. Chem. 22: 2266-2274.

Belanger, R.M., Smith, C.M., Corkum, L.D., and Zielinski, B.S. 2003. Morphology and histochemistry of the peripheral olfactory organ in the round goby, Neogobius melanostomus (Teleostei: Gobiidae). J. Morphol. 257: 62-71.

Beyers, D.W., and Farmer, M.S. 2001. Effects of copper on olfaction of Colorado pikeminnow. Environ. Toxicol. Chem. 20: 907-912.

Bjerselius, R., Winberg, S., Winberg, Y., and Zeipel, K. 1993. Ca ${ }^{2+}$ protects olfactory receptor function against acute $\mathrm{Cu}$ (II) toxicity in Atlantic salmon. Aquat. Toxicol. 25: 125-138.

Brown, S.B., Evans, R.E., Thompson, B.E., and Hara, T.J. 1982. Chemoreception and aquatic pollutants. In Chemoreception in fishes. Edited by T.J. Hara. Elsevier, Amsterdam. pp. 363-394.

Cousin, M.A., and Robinson, P.J. 2000. Two mechanisms of synaptic vesicle recycling in rat brain nerve terminals. J. Neurochem. 75: $1645-1653$.

Ferguson, S.S.G. 2001. Evolving concepts in G protein-coupled receptor endocytosis: the role in receptor desensitization and signaling. Pharmacol. Rev. 53: 1-24.

Gale, J.E., Marcotti, W., Kennedy, H.J., Kros, C.J., and Richardson, G.P. 2001. FM1-43 dye behaves as a permeant blocker of the hair-cell mechanotransducer channel. J. Neuorsci. 21: 7013-7025.

Gottofrey, J., and Tjälve, H. 1991. Axonal transport of cadmium in the olfactory nerve of the pike. Pharmacol. Toxicol. 69: 242-252.

Hamdani, E.H., and Døving, K.B. 2002. The alarm reaction in crucian carp is mediated by olfactory neurons with long dendrites. Chem. Senses. 27: 395-398.

Hamdani, E.H., Alaxander, G., and Døving, K.B. 2001. Projections of sensory neurons with microvilli to the olfactory tract indicates their participation in feeding behavior in crustacean carp. Chem. Senses. 39: 1139-1144.

Hansen, A., and Finger, T.E. 2000. Phyletic distribution of crypttype olfactory receptor neurons in fishes. Brain Behav. Evol. 55: 100-110.

Hansen, A., Rolen, S.H., Anderson, K., Morita, Y., Caprio, J., and Finger, T.E. 2003. Correlation between olfactory receptor cell type and function in the channel catfish. J. Neurosci. 23: 9328-9339.

Hansen, J.A., Rose, J.D., Jenkins, R.A., Gerow, K.G., and Bergman, J.L. 1999. Chinook salmon (Oncorhynchus tshawytscha) and rainbow trout (Oncorhynchus mykiss) exposed to copper: neurophysiological and histological effects on the olfactory system. Environ. Toxicol. Chem. 18: 1979-1991.

Hara, T.J. 1992. Mechanisms of olfaction. In Fish chemoreception. Edited by T.J. Hara. Chapman and Hall, New York. pp. 150-170.

Hara, T.J., Law, Y.M.C., and MacDonald, S. 1976. Effects of mercury and copper on the olfactory response in rainbow trout. J. Fish. Res. Board. Can. 33: 1568-1573.

Henkel, A.W., Simpson, L.L., Ridge, R.M.A.P., and Betz, W.J. 1996. Synaptic vesicle movements monitored by fluorescence recovery after photobleaching in nerve terminals stained with FM1-43. J. Neurosci. 16: 3960-3967.

Horning, M.S., and Trombley, P.Q. 2001. Zinc and copper influence excitability of rat olfactory bulb neurons by multiple mechanisms. J. Neurophysiol. 86: 1652-1660.

Horning, M.S., Blakemore, L.J., and Trombley, P.Q. 2000. Endogenous mechanisms of neuroprotection: role of zinc, copper, and carnosine. Brain Res. 852: 56-61.

Jarrard, H.E., Delaney, K.R., and Kennedy, C.J. 2004. Impacts of carbamate pesticides on olfactory neurophysiology and cholinesterase activity in coho salmon (Oncorhynchus kisutch). Aquat. Toxicol. 69:133-148.

Julliard, A.K., Saucier, D., and Astic, L. 1996. Time-course of apoptosis in the olfactory epithelium of rainbow trout exposed to a low copper level. Tiss. Cell. 28: 367-377.

Kay, A.R., Alfonso, A., Alford, S., Cline, H.T., Holgado, A.M., Sakmann, B., Snitsarev, V.A., Stricker, T.P., Takahashi, M., and Wu, L.-G. 1999. Imaging synaptic activity in intact brain and slices with FM1-43 in C. elegans, lamprey, and rat. Neuron, 24: 809-817.

Li, W., Ono, F., and Brehm, P. 2003. Optical measurements of presynaptic release in mutant zebrafish lacking postsynaptic receptors. J. Neurosci. 23:10467-10474.

Meyers, J.R., MacDonald, R.B., Duggan, A., Lenzi, D., Standaert, D.G., Corwin, J.T., and Corey, D.P. 2003. Lighting up the senses: FM1-43 loading of sensory cells through nonselective ion channels. J. Neurosci. 23: 4054-4065.

Mirza, R.S., and Chivers, D.P. 2001. Chemical alarm signals enhance survival of brook charr (Salvelinus fontinalis) during encounters with predatory chain pickerel (Esox niger). Ethology, 107: 989-1005.

Moran, D.T., Rowley, J.C., III, Aiken, G.R., and Jafek, B.W. 1992. Ultrastructural neurobiology of the olfactory mucosa on the brown trout, Salmo trutta. Microsc. Res. Tech. 23: 28-48.

Petris, M.J., Smith, K., Lee, J., and Thiele, D.J. 2003. Copperstimulated endocytosis and degradation of the human copper transporter, hCtr1. J. Biol. Chem. 278: 9639-9646.

Pyle, J.L., Kavalali, E.T., Choi, S., and Tsien, R.W. 1999. Visualization of synaptic activity in hippocampal slices with FM1-43 enabled by fluorescence quenching. Neuron, 24: 803-808.

Rhenberg, B.C., and Schreck, C.B. 1986. Acute metal toxicology of olfaction in coho salmon: behavior, receptors, and odor-metal complexation. Bull. Environ. Contam. Toxicol. 36: 579-586.

Rutkoski, N.J., Fitch, C.A., Yeiser, E.C., Dodge, J., Trombley, P.Q., and Levenson, C.W. 1999. Regulation of neuropeptide Y mRNA and peptide concentrations by copper in rat olfactory bulb. Mol. Brain Res. 65: 80-86.

Sandahl, J.F., Baldwin, D.H., Jenkins, J.J., and Scholz, N.L. 2004. Odor-evoked field potentials as indicators of sublethal neurotoxicity in juvenile coho salmon (Oncorhynchus kisutch) exposed to copper, chlorpyrifos, or esfenvalerate. Can. J. Fish. Aquat. Sci. 61: 404-413.

Sato, K., and Suzuki, N. 2001. Whole-cell response characteristics of ciliated and microvillus olfactory receptor neurons to amino acids, pheromone candidates and urine in rainbow trout. Chem. Senses, 26: 1145-1156.

Saucier, D., and Astic, L. 1995. Morpho-functional alterations in the olfactory system of rainbow trout (Oncorhynchus mykiss) and possible acclimation in response to long-lasting exposure to low copper levels. Comp. Biochem. Physiol. A, 112: 273-284.

Schlenk, D., Gollen, J.L., and Griffin, B.R. 1998. Efficacy of copper sulfate for the treatment of Ichthyophthiriasis in channel catfish. J. Aquat. Anim. Health, 10: 390-396.

Soller, J., Stephenson, J., Olivieri, K., Downing, J., and Olivieri, A.W. 2005. Evaluation of seasonal scale first flush pollutant loading and implications for urban runoff management. J. Environ. Manag. 76: 309-318.

Tallkvist, J., Henriksson, J., D’Argy, R., and Tjälve, H. 1998. Transport and subcellular distribution of nickel in the olfactory system of pikes and rats. Toxicol. Sci. 43: 196-203.

Tallkvist, J., Persson, E., Henriksson, J., and Tjälve, H. 2002. Cadmium-metallothionein interactions in the olfactory pathways of rats and pikes. Toxicol. Sci. 67: 108-113. 
Tjälve, H., Gottofrey, J., and Björklund, I. 1986. Tissue disposition of ${ }^{109} \mathrm{Cd}^{2+}$ in the brown trout (Salmo trutta) studied by autoradiography and impulse counting. Toxicol. Environ. Chem. 12: $31-45$.

Trombley, P.Q., and Shepherd, G.M. 1996. Differential modulation by zinc and copper of amino acid receptors from rat olfactory bulb neurons. J. Neurophysiol. 76: 2536-2546.

Wang, J., Luthey-Schulten, Z.A., and Suslick, K.S. 2003. Is the olfactory receptor a metalloprotein? Proc. Natl. Acad. Sci. U.S.A. 100: $3035-3039$.
Wheeler, A.P., Angermeier, P.L., and Rosenberger, A.E. 2005. Impacts of new highways and subsequent landscape urbanization on stream habitat and biota. Rev. Fish. Sci. 13: 141-164.

Winberg, S., Bjerselius, R., Baatrup, E., and Døving K.B. 1992. The effect of $\mathrm{Cu}$ (II) on the electro-olfactogram (EOG) of the Atlantic salmon (Salmo salar L) in artificial freshwater of varying inorganic carbon concentrations. Ecotoxicol. Environ. Saf. 24: $167-178$. 